\title{
USO DE LA KIWICHA (Amaranthus caudatus) COMO BASE PARA UN MEDIO DE CULTIVO NUTRITIVO NATURAL PARA ENTEROBACTERIAS
}

\author{
Rosario Polo S., \\ TOMÁs AGURTo S., \\ Julio PaLomino
}

RESUMEN

En el presente trabajo se propone la elaboración de un medio de cultivo a base de un cereal autóctono (Perú) por ser altamente nutritivo y que pueda competir con la soya y así se propone el Agar-Almidón-Kiwicha similar al Agar Almidón, reemplazando la Peptona y el Almidón por harina de Kiwicha respectivamente.

El análisis químico del grano de Kiwicha nos muestra que el contenido de Proteína es de $12.9 \%$ y de Almidón es de $62 \%$, cantidades que hacen posible que se pueda diseñar medios de cultivos de diversos contenidos para el crecimiento bacteriano, con las mismas características morfológicas semejantes al crecimiento en los medios de cultivo convencionales que contienen Peptona y Almidón.

\section{SUMMARY}

In this work the propose is to elaborate a bacterial medium culture with a peruvian bean to name "kiwicha" because is very nutritive similar to soy, in one nutritive agar replace to peptone and starch respectively.

The quimical study of kiwicha seed, demostrate the contain in protein is $12.9 \%$ and $62 \%$ of starch, quantity to posibility to do several bacterial culture media, with similar morpology of colonies grow in convencional medias with peptone and starch.

\section{INTRODUCCIÓN}

El presente trabajo tiene por finalidad proponer el diseño de medios de cultivo utilizando la harina de Kiwicha (A. Caudatus), reemplazando la cantidad de Peptona, medio de cultivo para el crecimiento bacteriano; mientras que en otro medio de cultivo se va a reemplazar la cantidad de Almidón para la prueba de Hidrólisis del Almidón, determinando así la técnica apropiada para la obtención de dichos medios de cultivo, y que en un futuro puedan aplicarse en los laboratorios de Microbiología porque este cereal es altamente nutritivo.

Las Enterobacterias desarrollan bien en medios ordinarios Agar o Caldo Nutritivo que son a base de Peptona o Triptosa y que van a ser reemplazados por este cereal peruano que es la Kiwicha (Amaranthus caudatus). (Koneman; 1,992).

El desarrollo normal de las características morfológicas en la formación de colonias en este nuevo medio de cultivo a base de kiwicha (Agar Kiwicha), acreditar la eficiencia de este substrato que se propone en el presente trabajo; lo que demuestra que puede utilizarse la harina de los granos de las plantas nativas del Perú, en la confección rutinaria de medios de cultivo para el desarrollo de bacterias; para que en el futuro puedan aplicarse en las tecnologías de materias primas de origen natural

\section{MATERIALESY MÉTODOS}

\section{A)MATERIALES:}

\section{A.1. Material Biológico:}

Se caracteriza la kiwicha (A. caudatus) cultivada en el Callejón de Huaylas (Ancash) de grano blanco amarillento y dulce (crudo y tostado).

\section{A.2. Medios de Cultivo:}

Agar Nutritivo

Agar-agar

Almidón soluble

Caldo Nutritivo

Peptona

\section{A.5. Cepas Microbianas:}

Escherichia coli.

Salmonella paratyphi B.

Klebsiella pneumoiae.

Proteus mirabilis.

Saccharomyces cerevisiae.

Bacillus subtilis.

Shigella flexnerii.

Enterobacter cloacae.

Klebsiella oxytoca.

Staphylococcus aureus. 


\section{B) MÉTODOS:}

\section{B.1. Método Experimental:}

B.1.1. Procesamiento: En el desarrollo de este trabajo se va a optar por las siguientes formas:

a) Kiwicha de Grano Crudo.

b). Kiwicha de Grano tostado.

La limpieza se realiza de forma manual, separando las pajas, cáscaras, y material raro, después se realiza el lavado para eliminar el polvo, tierra y a la vez humedecer el grano (el lavado se aplica en la kiwicha de grano crudo).

Considerando las dimensiones del grano de kiwicha y su dureza, para la molienda se utilizó una licuadora eléctrica y luego de cernir con un colador fino ( $\mathrm{lmm}$. De porosidad) se obtiene así la harina fina.

B.1.2.- Uso de la Kiwicha de Grano Crudo: Para determinar su uso se propuso 2 formas:

a) En agua fría.

b) En Agua caliente.

Para ambas formas se tomó 1 gr. de la harina y se le añadió $100 \mathrm{ml}$. de agua destilada y se mezcló, para luego filtrarlo, en la forma de agua caliente se hace hervir por 5 min. y luego se filtra.

B.1.3.- Uso de la kiwicha de Grano Tostado: Para determinar su uso se propuso 2 formas:

a) En agua fría

b) En Agua caliente.

Para ambas formas se tomó 1gr. de la Harina y se le añadió 100d. De agua destilada y se mezcló, para luego filtrarlo, en la forma de agua caliente se hace hervir por 5 min. Y luego se filtra.

B.1.4..- Determinación de la Harina de kiwicha a usarse: Para la preparación del nuevo medio de cultivo, Agar kiwicha; se determinó usar la harina de kiwicha de grano crudo en agua fría, ya que por la Prueba del Lugol esta muestra de harina no contiene Almidón al dar una reacción Negativa con el Lugol (color amarillo); mientras que en la harina de kiwicha de grano crudo (en agua caliente) y en la harina tostada (en agua caliente y fría) se observó la presencia de Almidón al dar una reacción positiva con el Lugol (color azul).

En el caso de utilizar la harina de grano crudo para reemplazar la Peptona presente en el Agar Nutritivo, se le realizará el análisis para determinar la cantidad de proteína que presenta el líquido que se obtiene al procesar la harina y que va a ser utilizado en la preparación del nuevo Medio de Cultivo.
De la misma manera se determinará la cantidad de Almidón presente en el líquido de las otras harinas, que van a ser utilizadas en la preparación de un medio de cultivo similar al Agar Almidón.

\section{PREPARACIÓN DEL MEDIO DE CULTIVO AGAR KIWICHA}

En la elaboración del medio de cultivo Agar Kiwicha se optó por preparar en tres concentraciones de harina de kiwicha de grano crudo disueltos en agua fría, al 10\%, $20 \%$ y $30 \%$ de harina de kiwicha presente en el nuevo medio de cultivo; Agar Kiwicha.

Se preparó los ingredientes similares al Agar Nutritivo tradicional y luego se mezcló con el líquido obtenido de la harina de kiwicha de grano crudo en agua fría; la mezcla es en cantidades iguales, obteniéndose el contenido de nutrientes similares al del medio de cultivo; luego se ajusta el pH a 7.2.

El medio de cultivo preparado Agar Kiwicha y el Agar Nutritivo se llevaron a esterilizar en autoclave a $15 \mathrm{lb}$. De presión a $121^{\circ} \mathrm{C}$. por $15 \mathrm{~min}$. para luego distribuirlos en placas petri estériles.

\section{A).- CULTIVO DE LAS CEPAS:}

Para determinar cual es la concentración más adecuada se sembró 4 cepas de Enterobacterias, en las concentraciones propuestas para observar cual de ellas es la mejor en el desarrollo de las bacterias. Para dicha determinación se utilizó las siguientes cepas de Enterobacterias:

1. Escherichia coli

2. Proteus mirabilis

3. Enterobacter cloacae

4. Salmonella paratyphi B

Debido a que las cepas se conservan refrigeradas, primero se les va a sembrar en Caldo Nutritivo para su activación por un tiempo de 24 hrs. Después de este tiempo con la ayuda del Asa de Koll en Aro (4 mm. De diámetro) se va a sembrar cada cepa en las placas petri correspondientes por el Método de Estrias sobre la Superficie, tanto en el nuevo medio de cultivo Agar Kiwicha como en el Agar Nutritivo (placa patrón). Las placas petri sembradas se llevaron a incubar en la estufa a $37^{\circ} \mathrm{c}$. Por $24 \mathrm{hrs}$.

\section{B).- CUANTIFICACIÓN DE COLONIAS:}

Para poder cuantificar las colonias de las cepas presentes en el medio de cultivo se realizó la siembra por medio de diluciones de la cepa utilizada en Agua Peptonada y luego se sembró por incorporación en el medio de cultivo Agar Kiwicha y en el Agar Nutritivo. Para esta prueba se utilizó las cepas que se encuentran en los Análisis 
Microbiológicos con más frecuencia como lo son: Escherichia coli y Salmonella paratyphi B.; siendo la primera Lactosa Positiva y la segunda Lactosa Negativa.

Cada cepa se cultivó en $10 \mathrm{ml}$. de Caldo Nutritivo a $37^{\circ} \mathrm{c}$ x $24 \mathrm{hrs}$., luego se saca $1 \mathrm{ml}$. del cultivo a $37^{\circ} \mathrm{c}$ x $24 \mathrm{hrs}$. luego se saca $1 \mathrm{ml}$. del cultivo en Caldo Nutritivo y se vierte en $9 \mathrm{ml}$. de Agua Peptonada (dilución -1), luego se mezcla bien y de este tubo se saca $1 \mathrm{ml}$. y se vierte en otro tubo con $9 \mathrm{ml}$. de Agua Peptonada (dilución -2) y así sucesivamente hasta diluir 7 veces el caldo de cultivo con la cepa (dilución-7).

Para la siembra se utilizó $1 \mathrm{ml}$. de Agua Peptonada de las diluciones $-1,-3,-5$ y -7 respectivamente, que se colocaron en cada placa petri y luego se le añadió $15 \mathrm{ml}$. del medio de cultivo (Agar Nutritivo y Agar Kiwicha), luego se mezcla por medio de movimientos rotatorios. Se deja enfriar y se lleva a incubar a $37^{\circ} \mathrm{c}$ x $24 \mathrm{hrs}$. y se cuantifica las colonias que se aprecian en las placas petri de cada medio de cultivo correspondiente.

\section{RESULTADOS}

\section{MEDIODE CULTIVO AGAR KIWICHA}

\section{CRECIMIENTO BACTERIANOENLAS CONCENTRACIONES PROPUESTAS}

\section{CEPA N $^{\circ}$ 1: Escherichia coli}

Concentración 20\%: Las colonias son pequeñas de color blanco cremosas. El crecimiento es abundante.

Agar Nutritivo: Las colonias son blanco cremosas. El crecimiento es abundante.

\section{CEPA N²: Proteus mirabilis}

Concentración 20\%: Las colonias son blanco cremosas y pequeñas. El crecimiento es abundante y de mejor aspecto.

Agar Nutritivo: Las colonias son blanco cremosas y pequeñas. El crecimiento es abundante.

\section{CEPA ${ }^{\circ}$ 3: Enterobacter cloacae:}

Concentración $20 \%$ : Las colonias son grandes y algo húmedas de color blanco cremosas. El crecimiento es abundante.
Agar Nutritivo: Las colonias son grandes, húmedas de color blanco cremosos. El crecimiento es abundante.

\section{$\mathrm{CEPA} \mathrm{N}^{\circ}$ 4: Salmonella paratyphi B:}

Concentración $20 \%$ : Las colonias son pequeñas, algo irregular de color crema. El crecimiento es abundante.

Agar Nutritivo: Las colonias son pequeñas, redondas de color crema. El crecimiento es abundante.

La comparación del medio de cultivo Agar Kiwicha con el Agar Nutritivo, en cuanto al desarrollo de las colonias, se observó que con $20 \%$ de harina de Kiwicha presente en el medio de cultivo diseñado, el crecimiento y aspecto de las colonias es similar al Agar Nutritivo.

Después de observar el crecimiento de cada cepa bacteriana se pasó a cuantificar. Demostrándose que el medio de cultivo Agar kiwicha, se puede utilizar para cuantificar las colonias de las bacterias de una muestra diluida o concentrada, ya que contiene los nutrientes necesarios para su desarrollo.

De los resultados se puede decir que ambos medios de cultivo son similarmente iguales, ya que los valores cuantificados de las colonias son muy similares, y se puede decir de que si se puede reemplazar el Agar Nutritivo por el Agar Kiwicha.

\section{DISCUSIÓN}

La propuesta de la modificación de dos medios de cultivo como lo es, el Agar Nutritivo y el Agar Almidón reemplazando la cantidad de Peptona y de Almidón por la harina de kiwicha respectivamente; es un trabajo que no ha sido realizado anteriormente, ya que los estudios realizados en los productos andinos son en su mayoría de carácter nutricional, ecológico y económico.

En este trabajo el uso de la harina de kiwicha cruda ( $\sin$ hervir) en la modificación del medio de cultivo Agar Nutritivo en Agar Kiwicha para la comprobación del crecimiento bacteriano, ha dado resultados favorables; ya que se ha comprobado que con la modificación realizada el crecimiento bacteriano de las cepas utilizadas es óptimo; salvo algunas modificaciones en la forma de las colonias observadas.

Nuestros resultados finales indican la modificación en algunos medios de cultivo, como el Agar Nutritivo y el Agar Almidón; utilizando la harina de kiwicha sea cruda o tostada según sea el caso; pudiendo de esta manera prepararse de forma rutinaria en algunos laboratorios. 


\section{CONCLUSIONES}

Se observó que el crecimiento de Enterobacterias es óptimo y que conservan sus características culturales.
Es posible reemplazar la cantidad de Peptona del Agar Nutritivo por la harina de kiwicha cruda sin hervor, para la preparación rutinaria del Agar Kiwicha.

\section{COMPOSICIÓN QUÍMICA DE LA SEMILLA DEL AMARANTOY OTROS GRANOS \\ (en 100 gr. de cereal)}

\begin{tabular}{|c|c|c|c|c|c|c|c|c|}
\hline $\begin{array}{l}\text { SEMILLA } \\
\text { COMPOSICIÓN Cauda }\end{array}$ & $\begin{array}{l}\text { A. } \\
\text { atus } \\
\text { (b) }\end{array}$ & $\begin{array}{l}\text { Soya } \\
\text { (b) }\end{array}$ & $\begin{array}{c}\text { Cañihua } \\
\text { (a) }\end{array}$ & $\begin{array}{c}\text { Cebada } \\
\text { (b) }\end{array}$ & $\begin{array}{l}\text { Maíz } \\
\text { (b) }\end{array}$ & $\begin{array}{l}\text { Quinua } \\
\text { (b) }\end{array}$ & $\begin{array}{l}\text { Trigo } \\
\text { (a) }\end{array}$ & $\begin{array}{c}\text { Arroz } \\
\text { (a) }\end{array}$ \\
\hline Calorías & 366 & 403 & 379 & 348 & 361 & 388 & 336 & 348 \\
\hline Humedad (\%) & 12.3 & 10 & 12.5 & 10.5 & 10.6 & 10.8 & 12.0 & 12.0 \\
\hline Proteína (gr. \%) & 12.9 & 34.1 & 17.6 & 9.7 & 9.4 & 14.6 & 8.6 & 5.9 \\
\hline Grasa (gr. \%) & 7.2 & 17.7 & 8.2 & 1.9 & 4.3 & 9.0 & 1.5 & 2.0 \\
\hline Carbohidratos (gr. \%) & 65.1 & 33.5 & 61.7 & 75.4 & 74.4 & 59.7 & 73.7 & 74.7 \\
\hline Fibra (gr. \%) & 6.7 & 4.9 & 11.0 & 6.5 & 1.8 & 3.2 & 0.4 & 0.6 \\
\hline Ceniza (gr. \%) & 2.5 & 4.7 & 2.1 & 2.5 & 1.3 & 2.7 & 2.3 & 2.1 \\
\hline Tiamina (mgr. \%) & 0.14 & 1.1 & 0.57 & 0.98 & 90.49 & 0.13 & 0.3 & 0.16 \\
\hline Riboflavina (mgr. \%) & 0.32 & 0.91 & 0.75 & 0.2 & 0.1 & 0.38 & 0.68 & 0.07 \\
\hline $\operatorname{Niacina}($ mgr. \%) & 1.0 & 2.2 & 1.56 & 7.2 & 1.9 & 1.1 & 2.85 & 3.85 \\
\hline Ac. Ascórbico (mgr.\%) & 3.0 & - & - & trazos & trazos & - & 2.5 & - \\
\hline
\end{tabular}

(a) Fuente de Información INCAP-11961.

(B) Fuente de Información Kidway y Smith citados por Sánchez Marroquín 1980.

\section{DETERMINACIÓNDELACANTIDADDE PROTEÍNA PRESENTEENELLÍQUIDODE KIWICHAA USAR}

El líquido de la Harina de Kiwicha de Grano Crudo (sin hervor), se hace secar por evaporación quedando la parte sólida, que se va a utilizar para determinar la cantidad de Proteína que se ha utilizado; se aplicó el método de MicroKendhalj, desarrollándose de la siguiente manera:

a.- Preparado: Se pesa 0.1 gr. de muestra sólida obtenida por evaporación y se le añade $2 \mathrm{ml}$. De Ácido Sulfúrico Concentrado, con 0,5 gr. de muestra analítica.

b.- Fase de Digestión: La mezcla anterior se pone en calentamiento en la cocina eléctrica por espacio de una hora y media, la reacción es rápida y se termina cuando la mezcla de un color negro pasa a un color verde claro transparente.

c.- Fase de Destilación: A la mezcla obtenida en la fase anterior se le añade $4 \mathrm{ml}$. de agua destilada y $10 \mathrm{ml}$. de Hidróxido de Sodio al $50 \%$ y se mezcla hasta disolver; y en otro matraz receptor se añade 3-4 gotas del indicador a utilizar que consiste en una mezcla de Rojo de Metilo con Azul de Metileno en Alcohol. Se prosigue a destilar teniendo cuidado en la recepción del destilado para que no haya pérdida alguna. Este proceso dura aproximadamente $30 \mathrm{~min}$. d.- Fase de Titulación: El líquido obtenido en la fase anterior se lleva a titular con Ácido Sulfúrico al 0.1N, observando el cambio de color del líquido de un color verde claro a un color gris azul o púrpura claro, que nos indica el equilibrio entre lo ácido y alcalino. Se mide el volumen de ácido gastado para los cálculos.

e.- Cálculo: Es de la siguiente manera:

Nitrógeno $=(\mathrm{Vm}-\mathrm{Vb}) \times 0.0014 \times 100$ Muestra (gr.)

Nitrógeno $=(0.6 \mathrm{ml} .-0) \times 0.0014 \times 100$ $0.1 \mathrm{gr}$.

Nitrógeno $=0.84 \%$.

Proteína $=$ Nitrógeno $\times \mathbf{6 . 2 5}$ gr.

Proteína $=0.84 \%$ X 6.25 gr.

Proteína $=5.25$ gr. $\%$

NOTA: Vm: Volumen de ácido sulfúrico gastado de la muestra.

Vb: Volumen de ácido sulfúrico gastado del blanco. 


\section{REFERENCIAS BIBLIOGRÁFICAS}

Bacigálupo, A. 1971. "Posibilidades de Utilización de la Quinua, Cañihua y otras semillas de uso común”. En Recursos Proteicos en América Latina. Guatemala. Pg.8

Betschart, J. 1981. Amaranths cruentus: Milling, charanteristics distribution of nutrients with: seed components, and the effects of tempeature on nutritional quality". Journal of Food Science. USA. Pg. 36

Bressani, A. 1984. "El Amaranto y su potencial", Boletín $\mathrm{N}^{\circ} 1 . \mathrm{Pg} .8$
Sánchez, A. 1980. "Potencial Agro-industrial del Amaranto". Centro de Estudios Económicos y Sociales del Tercer Mundo. México. Pg. 28.

Saunders, J. And Becker, R. 1983. “Amaranthus: A Potencial Food and Reel Resairce". Cereal Sciencie Tecnology. Pg. 29.

Sfent, J. 1980. "Protein Quality of Amaranth grain" Rodale Press Inc. pg. 10. 